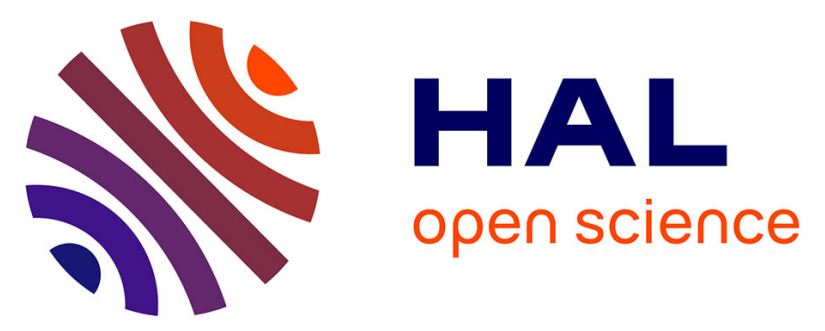

\title{
Carriage of genes for various extended-spectrum $\beta$-lactamases: a novel resistance strategy of in Poland
}

Danuta Dzierżanowska, Wanda Kamińska, Katarzyna Semczuk, Dariusz

Borowiec, Michal Matysiak, Anna Szumala-Kąkol, Rafal Gierczyński, Jan A.

Patzer

\section{To cite this version:}

Danuta Dzierżanowska, Wanda Kamińska, Katarzyna Semczuk, Dariusz Borowiec, Michal Matysiak, et al.. Carriage of genes for various extended-spectrum $\beta$-lactamases: a novel resistance strategy of in Poland. International Journal of Antimicrobial Agents, 2010, 35 (4), pp.392. 10.1016/j.ijantimicag.2009.12.010 . hal-00567284

\section{HAL Id: hal-00567284 \\ https://hal.science/hal-00567284}

Submitted on 20 Feb 2011

HAL is a multi-disciplinary open access archive for the deposit and dissemination of scientific research documents, whether they are published or not. The documents may come from teaching and research institutions in France or abroad, or from public or private research centers.
L'archive ouverte pluridisciplinaire HAL, est destinée au dépôt et à la diffusion de documents scientifiques de niveau recherche, publiés ou non, émanant des établissements d'enseignement et de recherche français ou étrangers, des laboratoires publics ou privés. 


\section{Accepted Manuscript}

Title: Carriage of genes for various extended-spectrum $\beta$-lactamases: a novel resistance strategy of Klebsiella pneumoniae in Poland

Authors: Danuta Dzierżanowska, Wanda Kamińska, Katarzyna Semczuk, Dariusz Borowiec, Michał Matysiak,

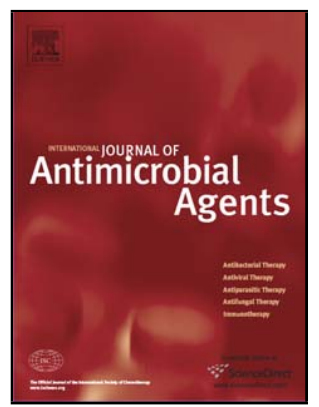
Anna Szumała-Kąkol, Rafał Gierczyński, Jan A. Patzer

PII:

DOI:

Reference: S0924-8579(10)00007-5

To appear in: International Journal of Antimicrobial Agents

Received date:

7-9-2009

Revised date:

3-12-2009

Accepted date:

4-12-2009

Please cite this article as: Dzierżanowska D, Kamińska W, Semczuk K, Borowiec D, Matysiak M, Szumała-Kąkol A, Gierczyński R, Patzer JA, Carriage of genes for various extended-spectrum $\beta$-lactamases: a novel resistance strategy of Klebsiella pneumoniae in Poland, International Journal of Antimicrobial Agents (2008), doi:10.1016/j.ijantimicag.2009.12.010

This is a PDF file of an unedited manuscript that has been accepted for publication. As a service to our customers we are providing this early version of the manuscript. The manuscript will undergo copyediting, typesetting, and review of the resulting proof before it is published in its final form. Please note that during the production process errors may be discovered which could affect the content, and all legal disclaimers that apply to the journal pertain. 


\section{Carriage of genes for various extended-spectrum $\beta$-lactamases: a novel resistance strategy of Klebsiella pneumoniae in Poland}

Danuta Dzierżanowska ${ }^{a}$, Wanda Kamińska ${ }^{a}$, Katarzyna Semczuk ${ }^{a}$, Dariusz Borowiec $^{\text {a }}$, Michał Matysiak ${ }^{b}$, Anna Szumała-Kąkol ${ }^{c}$, Rafał Gierczyński ${ }^{d}$, Jan A. Patzer ${ }^{a, *}$

${ }^{a}$ Department of Clinical Microbiology and Immunology, Children's Memorial Health Institute, Al. Dzieci Polskich 20, 04-730 Warsaw, Poland

${ }^{\mathrm{b}}$ Clinic of Paediatrics, Haematology and Oncology, Warsaw Medical University, ul. Marszałkowska 24, 00-576 Warsaw, Poland

${ }^{c}$ Bacteriological Laboratory, Clinical Gynaecological Hospital, Poznań University of Medical Sciences, ul. Polna 33, 60-535 Poznań, Poland

${ }^{d}$ Department of Bacteriology, National Institute of Public Health-National Institute of Hygiene, Chocimska 24, 00-791 Warsaw, Poland

\section{ARTICLE INFO}

Article history:

Received 7 September 2009

Accepted 4 December 2009

Keywords:

Klebsiella pneumoniae

Paediatric hospital

Multiple extended-spectrum $\beta$-lactamases 
ESBLs

Epidemiology

PFGE

* Corresponding author. Tel.: +48 22815 7271; fax: +48 228157275 .

E-mail address: j.patzer@czd.pl (J.A. Patzer). 


\section{ABSTRACT}

Among 110 randomly sampled strains from a collection of 247 extended-spectrum $\beta$ lactamase (ESBL)-producing clinical isolates of Klebsiella pneumoniae collected from hospitalised children in three paediatric hospitals in Poland, 64 strains (58.2\%) with multiple ESBLs were found, including five non-clonal strains (4.5\%) harbouring bla genes for ESBLs of three families (CTX-M, SHV and TEM). This is the first report of the emergence of triple ESBL-producing K. pneumoniae in Poland. In addition, $K$. pneumoniae strains harbouring bla genes for TEM-130 and TEM-132 ESBLs were detected in Poland for the first time. Epidemiological analysis of the multiple ESBLproducing K. pneumoniae isolates by pulsed-field gel electrophoresis (PFGE) revealed a relatively high genetic diversity between isolates producing the same combination of enzymes. Clonally related strains were uncommon. 


\section{Introduction}

Extended-spectrum $\beta$-lactamases (ESBLs) are the predominant resistance agents to oxyimino- $\beta$-lactams in clinical isolates of Gram-negative bacteria. In general, ESBLs are capable of hydrolysing penicillins, broad-spectrum cephalosporins and aztreonam. Owing to their rapid dissemination and diversity, ESBLs are an increasing problem worldwide [1]. Genes encoding ESBLs usually map on mobile genetic elements within large plasmids, which often spread horizontally. Initially, resistance to oxyimino-cephalosporins in Gram-negative rods was mainly due to dissemination of TEM- and SHV-type ESBLs. During the last 10 years, CTX-M-type ESBLs have become predominant [2]. ESBLs are frequently reported to be coproduced with penicillinases in clinical isolates of Enterobacteriaceae. Klebsiella pneumoniae strains producing multiple ESBLs were isolated for the first time in Chicago in 1990 and 1991. The strains were found to produce two different ESBLs of the same family (TEM-12 and TEM-10) in a single isolate [3]. Later, $K$. pneumoniae isolates producing multiple ESBLs of different families (TEM and SHV) were collected in Durban, South Africa [4]. Strains harbouring bla genes encoding for ESBLs of two or three different families emerged soon after [5]. In Poland, $K$. pneumoniae isolates simultaneously expressing CTX-M-3 and SHV- or TEM-type ESBLs were reported in 2002 [6]. The aim of this study was to determine the prevalence of multiple ESBL-producing K. pneumoniae isolates in three selected paediatric hospitals in Poland. Here we report 64 K. pneumoniae clinical isolates carrying bla genes for simultaneous expression of two or three different ESBLs. 


\section{Materials and methods}

\subsection{Bacterial strains}

A total of 110 strains was randomly selected from a collection of $247 \mathrm{ESBL}-$ producing K. pneumoniae isolates recovered from various clinical specimens from children hospitalised during 2000-2007 in the reference hospital Children's Memorial Health Institute $(\mathrm{CMHI})$ in Warsaw $(n=137)$, the neonatology ward in Poznań Medical University Hospital (PMUH) $(n=61)$ and the Clinic of Paediatrics, Haematology and Oncology in the Warsaw Medical University Hospital (WMUH) ( $n=$ 49). All selected strains were confirmed as ESBL-producers by the double-disk synergy test using a combination of cefotaxime, ceftazidime and amoxicillin/clavulanic acid [7].

2.2. Polymerase chain reaction (PCR) screening for extended-spectrum $\beta$-lactamse genes and DNA sequencing The conserved core regions of the bla $a_{C T X-M}, b / a_{S H V}$ and blatEM genes, which represent the most commonly reported ESBL families in Poland, were amplified by PCR [8] to identify isolates genetically competent to produce $\beta$-lactamases of different families simultaneously. Further, the exact ESBL genotypes were determined by DNA sequencing. Briefly, the core regions of the bla genes and the overlapping upstream and downstream gene fragments were amplified by PCR using the primers listed in Table 1. Both DNA strands of the PCR amplicons were sequenced using an automated fluorescent DNA sequencer ABI PRISM 310 (Applied Biosystems, Foster City, CA) and a BigDye ${ }^{\circledR}$ Terminator v3.1 Cycle Sequencing Kit (Applied Biosystems) in accordance with the manufacturer's 
instructions. Primers for PCR and DNA sequencing were the same. FinchTV V 1.4 and CLC Free Workbench V 6.0 software were used for processing of the sequencing data and to assemble the complete gene sequences.

\subsection{Antimicrobial susceptibility testing}

Minimum inhibitory concentrations of cefotaxime, ceftazidime, cefepime, piperacillin/tazobactam, ciprofloxacin, imipenem, meropenem and ertapenem were determined for each multiple ESBL-producing isolate by the agar dilution method on Iso-Sensitest agar [9]. Quality control was performed using strains Escherichia coli ATCC 25922 and K. pneumoniae ATCC 70060.

\subsection{Pulsed-field gel electrophoresis (PFGE)}

Isolates revealing a multiple ESBL genotype were subjected to PFGE typing with a CHEF DR II System (Bio-Rad, Hercules, CA). Briefly, agarose-embedded genomic DNA was digested with Xbal (Fermentas, Vilnius, Lithuania) and digestion products were separated in 1\% w/v agarose gel (Pulsed Field Certified Agarose; Bio-Rad) in TBE buffer [45 mM Tris-base, $45 \mathrm{mM}$ boric acid, $1 \mathrm{mM}$ ethylene diamine tetra-acetic acid (EDTA), $\mathrm{pH} 8.0]$. Electrophoresis was carried out at $6 \mathrm{~V} / \mathrm{cm}$ at $14{ }^{\circ} \mathrm{C}$ for $10 \mathrm{~h}$ with a switch time of $5 \mathrm{~s}$ to $15 \mathrm{~s}$, followed by $10 \mathrm{~h}$ with a switch time of $15 \mathrm{~s}$ to $45 \mathrm{~s}$ using a CHEF DR II System.

A dendrogram illustrating the genetic similarity of the multiple ESBL-producing isolates was generated using the Molecular Analyst Program (Bio-Rad). 


\section{Results and discussion}

Among the 110 tested strains of K. pneumoniae, 46 carried a single bla gene encoding for ESBL, whilst 64 strains harboured bla genes for at least two ESBLs of different families (Table 2). The majority of isolates producing a single ESBL harboured the blaстХ-м-3 gene (39/46) and the remaining isolates carried the following genes: bla $\mathrm{SHV}_{-5}(n=3)$; bla $=1$ ). Fifty-nine isolates and five isolates, respectively, were found to carry two or three bla genes for different ESBL families.

The combination of bla $a_{\mathrm{CTX}-\mathrm{M}-3}$ with bla $\mathrm{TTMM}-48_{8}$ or bla SHV-5 $_{5}$ predominated in isolates producing two ESBLs (dual ESBLs). The less common bla combination with blaTEM-48 or blaTEM-47, found in strains isolated from $\mathrm{CMHI}$ only. The bla TEM genes for TEM-130 and TEM-132 were detected in K. pneumoniae strains producing two ESBLs. Interestingly, these two TEM variants have not been reported in Poland. TEM-130 has not yet been fully described. Its amino acid sequence differs from TEM-129 by a single substitution (D35P)

(http://www.lahey.org/Studies/temtable.asp). Therefore, in this study TEM-130 was considered as the ESBL. TEM-132, first reported in 2005 , was originally found in neighbouring Slovakia [10]. Notably, 36 of the dual ESBL-producing K. pneumoniae isolates tested in this study were collected in $\mathrm{CMHI}$, whereas only 23 were isolated from patients in the two regional hospitals $\mathrm{PMUH}$ and $\mathrm{WMUH}$. All the isolates genetically competent to produce three ESBLs (triple ESBL genotype) were collected exclusively from $\mathrm{CMHI}$ patients. They had the following four genotypes: (i) bla

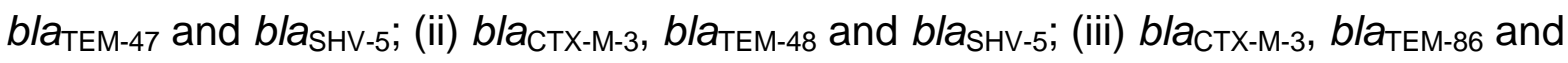
$b_{\mathrm{SHV}-5}$; and (iv) bla $\mathrm{a}_{\mathrm{CTX}-\mathrm{M}-15}, b / a_{\mathrm{TEM}-48}$ and blasHV-5. The prevalence of isolates 
showing a multiple ESBL genotype in $\mathrm{CMHI}$ was higher (67.2\%) than in $\mathrm{PMUH}$ (57.9\%) and WMUH (40.0\%). In contrast to the two regional hospitals, $\mathrm{CMHI}$ is the reference paediatric hospital to which serious cases from the whole of Poland are admitted. Before admission to $\mathrm{CMHI}$, many patients had prolonged or multiple hospitalisation events in a primary-care hospital, often connected with one or two antibiotic therapies.

All the multiple ESBL-producing K. pneumoniae strains were susceptible to imipenem, meropenem and ertapenem, and some were susceptible to piperacillin/tazobactam (Table 2). These strains were also susceptible to ciprofloxacin, which is in contrast to reports by Paterson et al. [11] and Damjanova et al. [12] who found a close relationship between ESBL production and ciprofloxacin resistance in K. pneumoniae. This may be due to the strongly limited consumption of fluoroquinolones in paediatric hospitals.

It is noteworthy that the majority of the multiple ESBL genotypes observed in this study were composed of genes encoding for ESBL variants that are common in Poland $[13,14]$. This finding may argue for self-dependent acquisition of the most common genes encoding ESBL by $K$. pneumoniae clinical isolates. It was particularly interesting to determine whether $K$. pneumoniae isolates sharing the same multiple ESBL genotype are clonal. Therefore, all 110 isolates were subjected to PFGE. The majority of the multiple ESBL-producing isolates from $\mathrm{CMHI}$ were non-clonal with a genetic similarity $<70 \%$ (Fig. 1). In contrast, the multiple ESBL-producing isolates from both local hospitals (PMUH and WMUH) were mostly clonal. Two clones covering six and three isolates and only two non-clonal ones were found in PMUH. 
Similarly, five clones of two isolates each, together with only two non-clonal isolates, were detected among the multiple ESBL-producing isolates from WMUH. Findings from these two local hospitals may argue for an enhanced epidemic potential of $K$. pneumoniae harbouring multiple bla genes for ESBLs.

Multiple ESBL-producing K. pneumoniae appear to occur worldwide. Among bloodstream K. pneumoniae isolates collected in 12 hospitals in Argentina, Australia, Belgium, South Africa, Taiwan, Turkey and the USA, up to $19.2 \%$ were found to produce multiple ESBLs [5]. Isolates of such a phenotype may be even more common. Recently, it has been reported that $44 \%$ of ESBL-producing isolates of $E$. coli, K. pneumoniae and Proteus mirabilis harboured bla genes for multiple ESBLs [15].

In Poland, the last country-wide survey on ESBL-producing Enterobacteriaceae was conducted between November 2003 and January 2004 [13]. This survey showed that $1.5 \%$ of 264 isolates collected in regional secondary-care hospitals co-produced two different ESBLs (CTX-M-15 and SHV-5). No isolates capable of producing three different ESBLs were found. In contrast, the results of this study showed that $58.2 \%$ of ESBL-producing K. pneumoniae isolates revealed a multiple ESBLs genotype. This could be explained by differences in studied patients, bacterial species and the study period. The current study was focused on K. pneumoniae, which is known to develop novel resistance traits rapidly. The tested isolates were collected from patients hospitalised between 2000 and 2007, mostly from the reference hospital $(\mathrm{CMHI})$. It is noteworthy that the majority of the multiple $\mathrm{ESBL}$-producing isolates (82.8\%) were collected after 2003. All the triple ESBL-producing isolates emerged in 
$\mathrm{CMHI}$ after 2004. In light of this, it may be supposed that the accumulation of multiple bla genes for different ESBLs in $K$. pneumoniae is tending to increase in Poland. Further studies are therefore required to deepen our knowledge of mechanisms leading to the selection and dissemination of multiple ESBL-expressing isolates.

\section{Funding}

This work was supported by the Polish State Committee for Scientific Research (grant number 2 P05D 057 29).

\section{Competing interests}

None declared.

\section{Ethical approval}

Not required. 


\section{References}

[1] Bradford PA. Extended-spectrum $\beta$-lactamases in the 21st century: characterization, epidemiology, and detection of this important resistance threat. Clin Microbiol Rev 2001;14:933-51.

[2] Livermore DM, Canton R, Gniadkowski M, Nordmann P, Rossolini GM, Arlet G, et al. CTX-M: changing the face of ESBLs in Europe. J Antimicrob Chemother 2007;59:165-74.

[3] Bradford PA, Cherubin CE, Idemyor V, Rasmussen BA, Bush K. Multiply resistant Klebsiella pneumoniae strains from two Chicago hospitals: identification of the extended-spectrum TEM-12 and TEM-10 ceftazidime-hydrolyzing $\beta$-lactamases in a single isolate. Antimicrob Agents Chemother 1994;38:761-6.

[4] Essack SY, Hall LM, Pillay DG, McFadeyen ML, Livermore DM. Complexity and diversity of Klebsiella pneumoniae strains with extended-spectrum $\beta$-lactamases isolated in 1994 and 1996 at a teaching hospital in Durban, South Africa. Antimicrob Agents Chemother 2001;45:88-95.

[5] Paterson DL, Hujer KM, Hujer AM, Yeiser B, Bonomo MD, Rice LB, et al. Extended-spectrum $\beta$-lactamases in Klebsiella pneumoniae bloodstream isolates from seven countries: dominance and widespread prevalence of SHV- and CTXM-type $\beta$-lactamases. Antimicrob Agents Chemother 2003;47:3554-60.

[6] Baraniak A, Fiett J, Sulikowska A, Hryniewicz W, Gniadkowski M. Countrywide spread of CTX-M-3 extended-spectrum $\beta$-lactamase-producing microorganisms of the family Enterobacteriaceae in Poland. Antimicrob Agents Chemother 2002;46:151-9. 
[7] Empel J, Baraniak A, Literacka E, Mrówka A, Fiett J, Sadowy E, et al. Molecular survey of $\beta$-lactamases conferring resistance to newer $\beta$-lactams in Enterobacteriaceae isolates from Polish hospitals. Antimicrob Agents Chemother 2008;52:2449-54.

[8] Jarlier V, Nicolas MH, Fournier G, Phillipon A. Extended broad-spectrum $\beta$ lactamases conferring transferable resistance to newer $\beta$-lactam agents in Enterobacteriaceae: hospital prevalence and susceptibility patterns. Rev Infect Dis 1988;10:867-78.

[9] Gierczyński R, Szych J, Rastawicki W, Jagielski M. The molecular characterisation of the extended-spectrum $\beta$-lactamase (ESBL) producing strain of Salmonella enterica serovar Mbandaka isolated in Poland. Acta Microbiol Pol 2003;52:183-90.

[10] Clinical and Laboratory Standards Institute. Performance standards for antimicrobial susceptibility testing. Seventeenth informational supplement. Document M100-S17. Wayne, PA: CLSI; 2007.

[11] Zarnayová M, Siebor E, Péchinot A, Duez JM, Bujdáková H, Labia R, et al. Survey of Enterobacteriaceae producing extended-spectrum $\beta$-lactamases in a Slovak hospital: dominance of SHV-2a and characterization of TEM-132. Antimicrob Agents Chemother 2005;49:3066-9.

[12] Paterson DL, Mulazimoglu L, Casellas JM, Ko WC, Goossens H, Von Gottberg A, et al. Epidemiology of ciprofloxacin resistance and its relationship to extended-spectrum $\beta$-lactamase production in Klebsiella pneumoniae isolates causing bacteremia. Clin Infect Dis 2000;30:473-8.

[13] Damjanova I, Tóth A, Pászti J, Hajbel-Vékony G, Jakab M, Berta J, et al. Expansion and countrywide dissemination of ST11, ST15 and ST147 
ciprofloxacin-resistant CTX-M-15-type $\beta$-lactamase-producing Klebsiella pneumoniae epidemic clones in Hungary in 2005-the new 'MRSAs'? J Antimicrob Chemother 2008;62:978-85.

[14] Baraniak A, Fiett J, Mrówka A, Walory J, Hryniewicz W, Gniadkowski M. Evolution of the TEM-type extended-spectrum $\beta$-lactamases in clinical Enterobacteriaceae strains in Poland. Antimicrob Agents Chemother 2005;49:1872-80.

[15] Jones CH, Tuckman M, Keeney D, Ruzin A, Bradford PA. Characterization and sequence analysis of extended-spectrum- $\beta$-lactamase-encoding genes from Escherichia coli, Klebsiella pneumoniae and Proteus mirabilis isolates collected during tigecycline phase 3 clinical trials. Antimicrob Agents Chemother 2009;53:465-75. 
Fig. 1. Dendrogram of the clonal relationship of multiple extended-spectrum $\beta$ lactamase (ESBL)-producing Klebsiella pneumoniae isolates from the reference hospital Children's Memorial Health Institute $(\mathrm{CMHI})$ in Warsaw. The dendrogram was generated from pulsed-field gel electrophoresis (PFGE) patterns of Xbaldigested genomic DNA. Each isolate is characterised by a number (culture identifier) and the multiple ESBL genotype. 


\section{Table 1}

Nucleotide sequences of polymerase chain reaction (PCR) primers used in the study

\begin{tabular}{|c|c|c|c|c|c|}
\hline Gene & Fragment & Forward $\left(5^{\prime} \rightarrow 3^{\prime}\right)$ & Reverse $\left(5^{\prime} \rightarrow 3^{\prime}\right)$ & Size (bp) & Reference \\
\hline blaстх-м & Upstream & CTTTCGGAAGCATAAAATCGG & CTCAGCCAGTGACATCGTCC & 472 & This study \\
\hline bla & Core & TGCAGTACCAGTAAGGTGATGG & CCAGATAACCGCGATATCGTTG & 546 & [8] \\
\hline blactX-M & Downstream & TGGTGACATGGATGAAAGGC & GCACTTTTGCCGTCTAAGGC & 311 & This study \\
\hline$b l a \mathrm{TEM}$ & Upstream & CGCTCATGAGACAATAACC & AAGGATCTTCACCTAGATCC & 379 & This study \\
\hline blaTEM & Core & AGTTCTGCTATGTGGTGCGG & GCTAGAGTAAGTAGTTCGCC & 387 & [8] \\
\hline bla & Downstream & AGCCATACCAAACGACGAGC & AAGGATCTTCACCTAGATCC & 439 & This study \\
\hline blasHV & Upstream & AAGAGGAATTGTGAATCAGC & GATCCTGCTGGCGATAGTGG & 387 & This study \\
\hline blasHV & Core & GAGCGAAAGATCCACTATCG & CCTCATTCAGTTCCGTTTCC & 241 & [8] \\
\hline blasHV & Downstream & GATCGGCGACAACGTCACC & TTAGCGTTGCCAGTGCTCGATC & 412 & This study \\
\hline
\end{tabular}




\section{Table 2}

Molecular characterisation of the bla genes among multiple extended spectrum $\beta$-lactamse (ESBL)-producing Klebsiella pneumoniae $(n=64)$ and activity of selected antibiotics against tested isolates

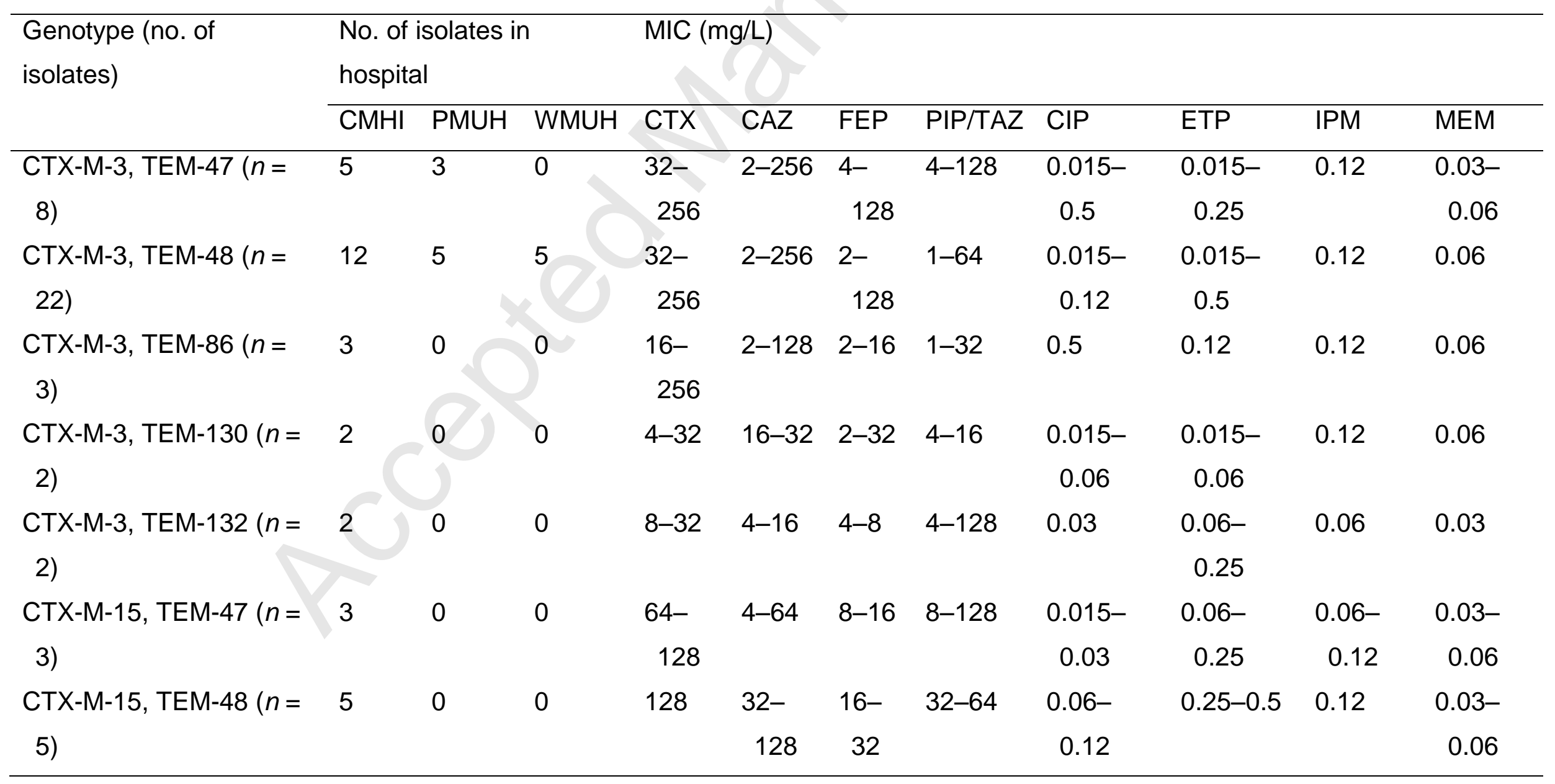




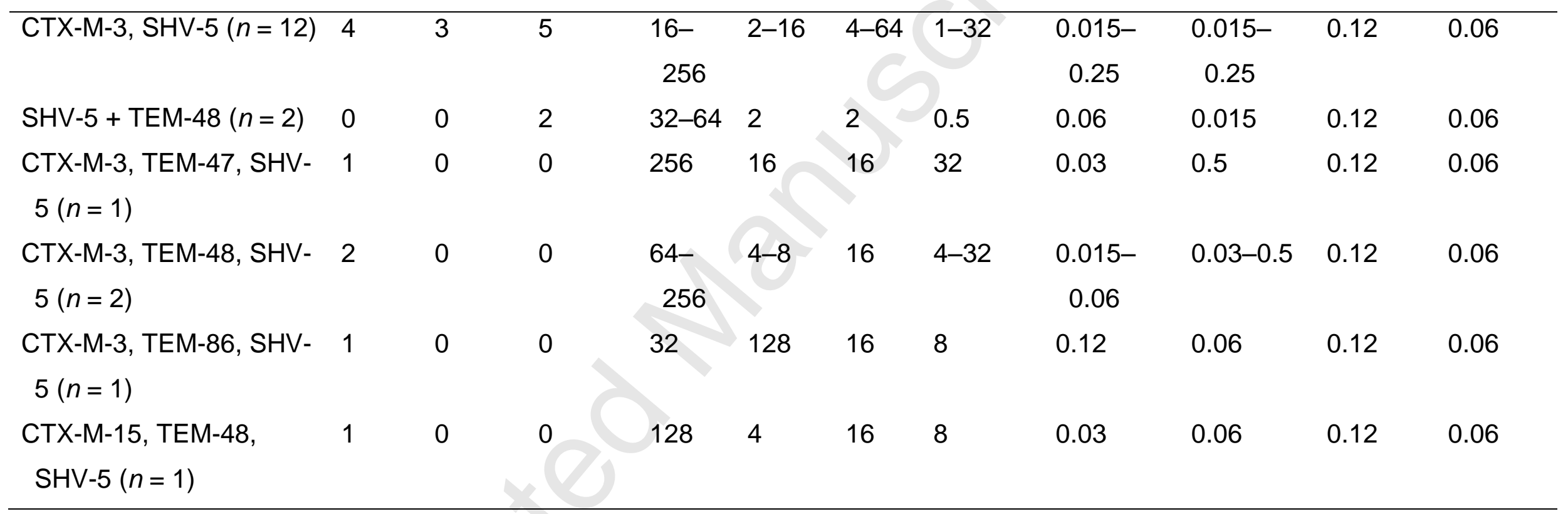

CMHI, Children's Memorial Health Institute; PMUH, Poznań Medical University Hospital; WMUH, Warsaw Medical University Hospital; MIC, minimum inhibitory concentration; CTX, cefotaxime; CAZ, ceftazidime; FEP, cefepime; PIP/TAZ,

piperacillin/tazobactam; CIP, ciprofloxacin; ETM, ertapenem; IPM, imipenem; MEM, meropenem. 
Distance

$\begin{array}{lllllll}40 & 50 & 60 & 70 & 80 & 90 & 100\end{array}$

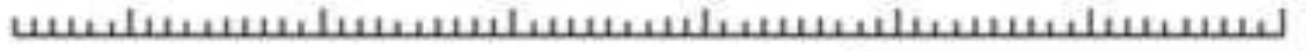

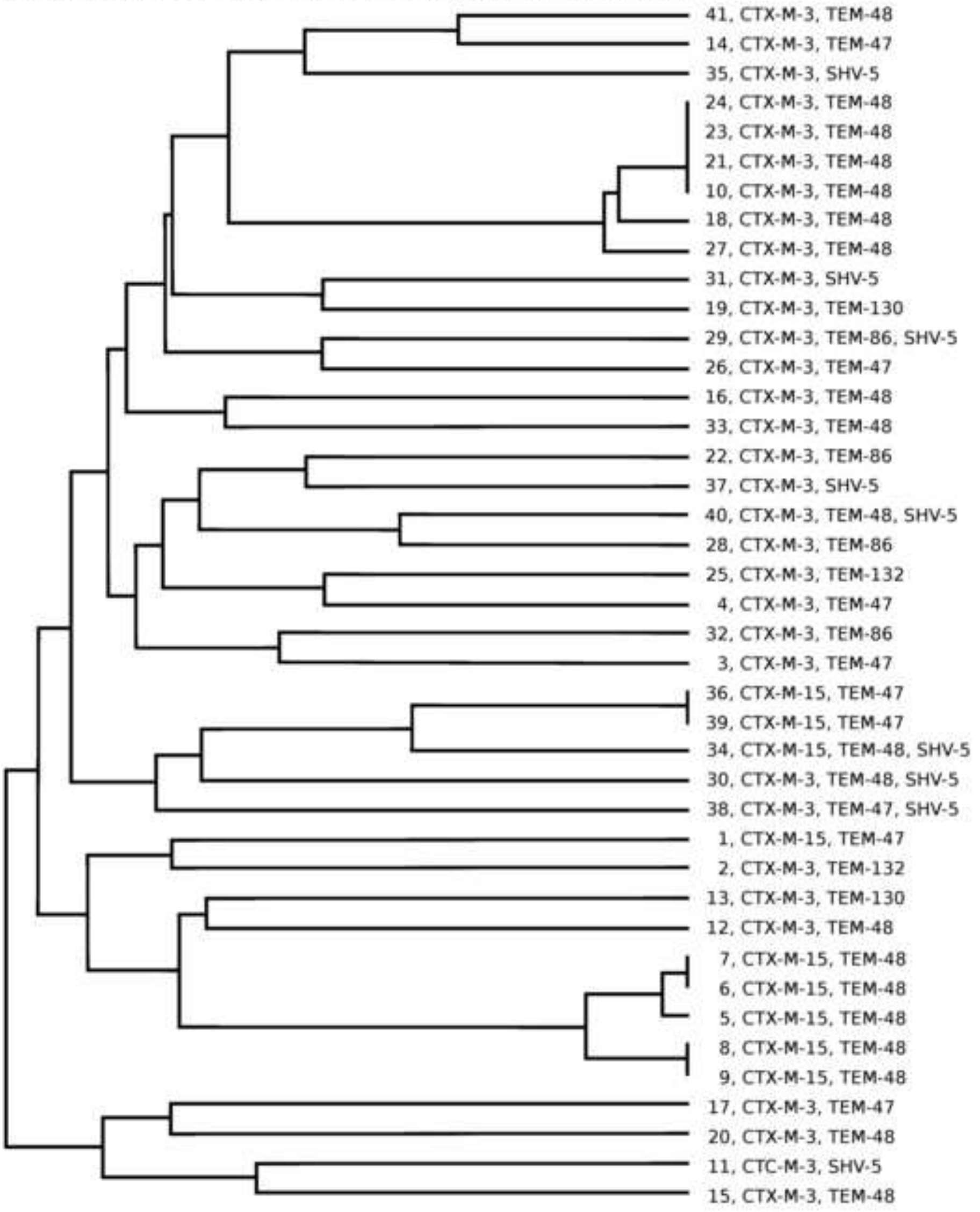

